\title{
Pre-existing caverns in salt formations could be the major cause of sinkhole hazards along the coast of the Dead Sea
}

\author{
A. Legchenko, ${ }^{1}$ M. Ezersky, ${ }^{2}$ M. Boucher, ${ }^{3}$ C. Camerlynck, ${ }^{4}$ A. Al-Zoubi, ${ }^{5}$ \\ and K. Chalikakis ${ }^{1}$ \\ Received 29 July 2008; revised 1 September 2008; accepted 4 September 2008; published 9 October 2008.
}

[1] Since 1990 hundreds of sinkholes have appeared along the coast of the Dead Sea. In the literature the rapid development of sinkholes is explained as a result of a drop in the level of the Dead Sea. This model assumes very fast dissolution of large volumes of salt and the creation of new caverns that cause sinkholes in 10 to 20 years. However, the results of our geophysical study do not confirm the fast dissolution assumption. To explain the available field observations, we propose the following model: (1) slow dissolution of salt (much longer than 20 years) with the creation of caverns without development of sinkholes; (2) sinkhole development is triggered by the lowering of the groundwater level because the rocks overlying the salt formation become unsaturated; (3) the time of sinkhole appearance is controlled by the mechanical properties of the rocks that overlie pre-existing caverns. Citation: Legchenko, A., M. Ezersky, M. Boucher, C. Camerlynck, A. Al-Zoubi, and K. Chalikakis (2008), Pre-existing caverns in salt formations could be the major cause of sinkhole hazards along the coast of the Dead Sea, Geophys. Res. Lett., 35, L19404, doi:10.1029/2008GL035510.

\section{Introduction}

[2] During the last 20 years hundreds of sinkholes have appeared along the Dead Sea shoreline in both Israel and Jordan. There is obvious potential for further collapses beneath main highways and near or under hotels and other structures. Thus, sinkhole hazards threaten the economic development of the Dead Sea basin. Results of geological and geophysical investigations reveal that sinkholes are caused by large caverns in a buried salt layer. The development of sinkholes is triggered by progressive lowering of the level of the Dead Sea. Different models explaining the phenomenon have been developed [Abelson et al., 2003; Arkin and Gilat, 2000; Frumkin and Raz, 2001].

[3] Various protective measures have been proposed for the hazard area [Taqieddin et al., 2000; Yechieli et al., 2006]. All these engineering solutions are very expensive and may cause serious environmental problems. The effectiveness of each of the solutions also depends on a correct understanding of the phenomenon. Thus, the danger exists that the protection measures based on incomplete model

\footnotetext{
${ }^{1}$ LTHE, Institut de Recherche pour le Développement, Grenoble, France.

${ }^{2}$ Engineering Geophysics, Geophysical Institute of Israel, Lod, Israel.

${ }^{3} \mathrm{HSM}$, Institut de Recherche pour le Développement, Montpellier, France.

${ }^{4}$ UMR 7619 Sisyphe, Université Pierre et Marie Curie (Paris 6), Paris, France.

${ }^{5}$ Engineering Faculty, Al-Balqa' Applied University, Salt, Jordan.
}

Copyright 2008 by the American Geophysical Union. 0094-8276/08/2008GL035510 would be more harmful than sinkholes. The field verification of the sinkhole development models was one of the major goals of our geophysical study.

\section{Sinkholes in the Dead Sea Basin}

[4] The area of investigation is located in the southern part of the Dead Sea in both Israel and Jordan and is a part of the active Dead Sea Transform. The subsurface is composed of limestone, dolomite and some marl. Near the Dead Sea shoreline, the shallow part of the subsurface (down to approximately $150 \mathrm{~m}$ ) is composed of sand and gravel with intercalated salt and clay sediments. The salt body ranges from a few meters to a few kilometers in thickness [Garfunkel and Ben-Avraham, 1996].

[5] Since 1970 the level of the Dead Sea is progressively diminishing. The drop in the Dead Sea level is accompanied by a corresponding lowering of the groundwater level and by the intrusion of fresh water into the coastal aquifer [Yechieli, 2000]. In Israel, the process of sinkhole development began in 1990 in the southern part of the Dead Sea coast and slowly spread to the north. In Jordan, reliable records about sinkhole development have existed since 1985 [Taqieddin et al., 2000].

[6] In the literature sinkhole phenomenon was explained by the dissolution of buried salt layer [Frumkin and Raz, 2001; Yechieli et al., 2006]. According to the salt dissolution model, the drop in the Dead Sea level changes the fresh - saline water interface thus creating the contact between the salt layer and fresh water. When the Dead Sea level was high, the salt layer was protected by very saline water. Thus, the appearance of sinkholes depends upon the location of the salt layer and the fresh - saline water interface. This model assumes creation of large cavities in the subsurface in 10 to 20 years. However, both the exact dynamics of groundwater and the cavitation process itself remain the subject of much debate and no comprehensive model exists today for sinkhole development in the Dead Sea area.

\section{Method}

[7] In our study we used three surface geophysical methods: magnetic resonance sounding (MRS), seismic refraction and transient electromagnetic (TEM).

[8] MRS method was used to detect subsurface caverns [Legchenko and Valla, 2002]. MRS is able to reliably identify water-filled caverns and channels [Vouillamoz et al., 2003]. For identifying caverns, the relaxation time $T_{1}$ is the most reliable parameter. The MRS signal generated by water in caverns is characterized by a long relaxation time $\left(T_{1}>800 \mathrm{~ms}\right)$ and the signal by water in a porous 


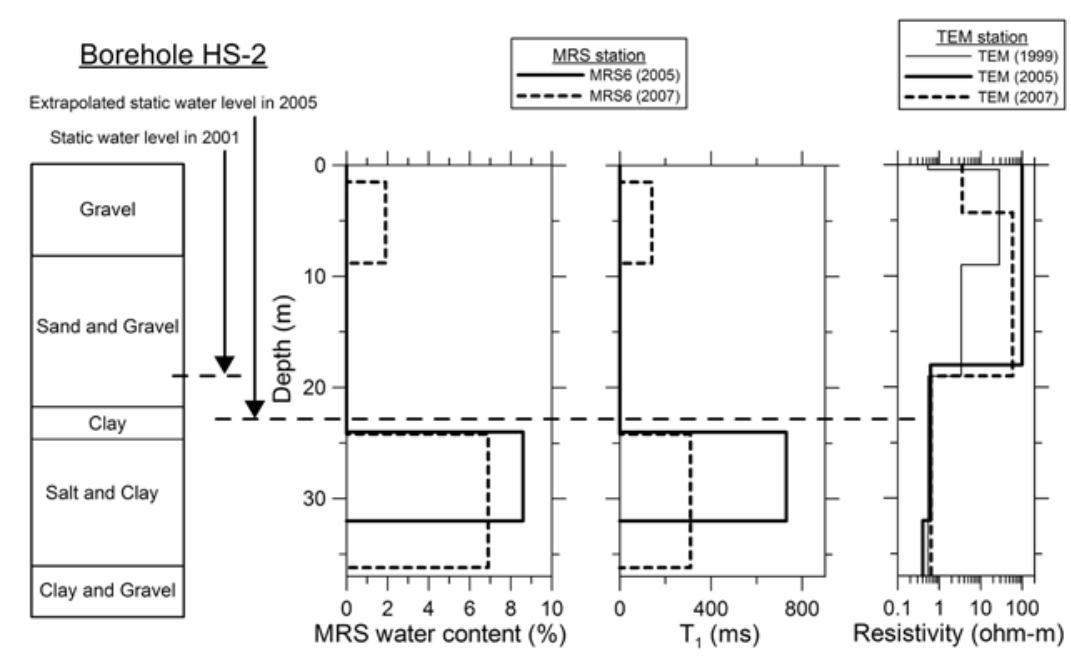

Figure 1. Example of MRS and TEM results near borehole HS-2 (Nahal Hever).

medium by a shorter relaxation time $\left(T_{1}<400 \mathrm{~ms}\right)$ [Legchenko et al., 2008]. However, the resolution of MRS may be not sufficient for accurately resolving water in caverns and water in porous medium when both formations are present. Consequently, we arbitrarily assume the threshold of $T_{1}>450 \mathrm{~ms}$ to be a signature of water-filled caverns. MRS measurements in Israel and Jordan were carried out using NUMIS ${ }^{\text {plus }}$ instrument (IRIS Instruments, France). In Israel we used a square loop $\left(100 \times 100 \mathrm{~m}^{2}\right)$ and in Jordan an eight-shape loop $\left(50 \times 50 \mathrm{~m}^{2}\right)$.

[9] Seismic refraction measurements were used to identify the salt formations. In the Dead Sea area salt is characterized by a higher P-wave velocity $V_{p}$ than surrounding sediments. In our study we set the threshold $V_{p}>$ $2900 \mathrm{~m} / \mathrm{s}$ to be a signature of buried salt [Ezersky, 2006]. Data processing was done with the REFRINT software [Shtivelman, 1995] using two interpretation methods: general reciprocal method (GRM) [Palmer, 1986] and slope intercept method (SIM). Seismic data acquisition in Israel was carried out using the 48-channel StrataView seismic recorder by Geometrics Inc (Canada). The DIGIPULSE source was applied at five points on every refraction line.

[10] TEM measurements allow non-invasive estimation of groundwater salinity [Kafri et al., 1997]. The TEM FAST 48 HPC system (AEMR, Holland) was used with coincident transmitter-receiver square loop $\left(25 \times 25 \mathrm{~m}^{2}\right)$. Field data were interpreted with 1D inversion (Interpex Ltd., IX1D v.3 inversion software, 2006, available at http://www.interpex. com/SoftwareIndex.htm).

\section{Results}

[11] In the southern part of Nahal Hever (Israel), MRS and TEM measurements were performed in 2005 and 2007. TEM results and borehole data obtained in 1999 are also available [Shtivelman et al., 1999; Yechieli et al., 2006]. Comparison of MRS and TEM results near borehole HS-2 (Figure 1) shows that a large cavern revealed by borehole was also reliably identified by MRS in $2005\left(T_{1}>450 \mathrm{~ms}\right)$. However, the cavern was not detected by MRS in 2007. TEM shows that the variations of the resistivity within the aquifer between 1999 and 2007 are insignificant. Above the aquifer, the resistivity observed in 2005 and 2007 is larger in comparison with 1999. It is explained by open pits appeared after 2001. Seismic measurements (Figure 2) reveal high velocities $\left(V_{p}>2900 \mathrm{~m} / \mathrm{s}\right)$ that correspond to the salt formation. In Figure 2, the salt edge is resolved as a band because of the limited resolution of seismic refraction measurements and subsurface heterogeneity. MRS reveals long relaxation times in the central part of the area thus suggesting water-filled caverns. In 1999 the microgravity located an anomaly corresponding to subsurface caverns at approximately the same place as MRS in 2005 [Rybakov et al., 2001]. Comparison of MRS results obtained in 2007 with those obtained in 2005 reveals that the border between long and short relaxation times has shifted about one hundred meters to the north. We think this shift may reflect the filling of the caverns with soil when the sinkholes were developing. Monitoring of sinkholes appearance was systematically carried out by the Geological Survey of Israel (GSI) and published in GSI reports [e.g., Abelson et al.,

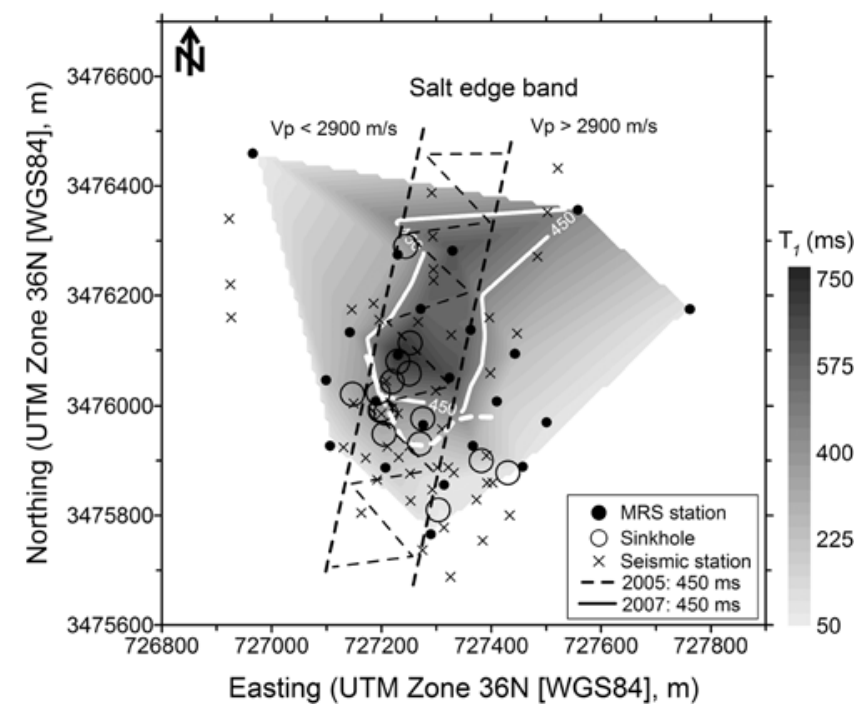

Figure 2. Map of the MRS relaxation time in Nahal Hever. The salt edge band was located after seismic results. 


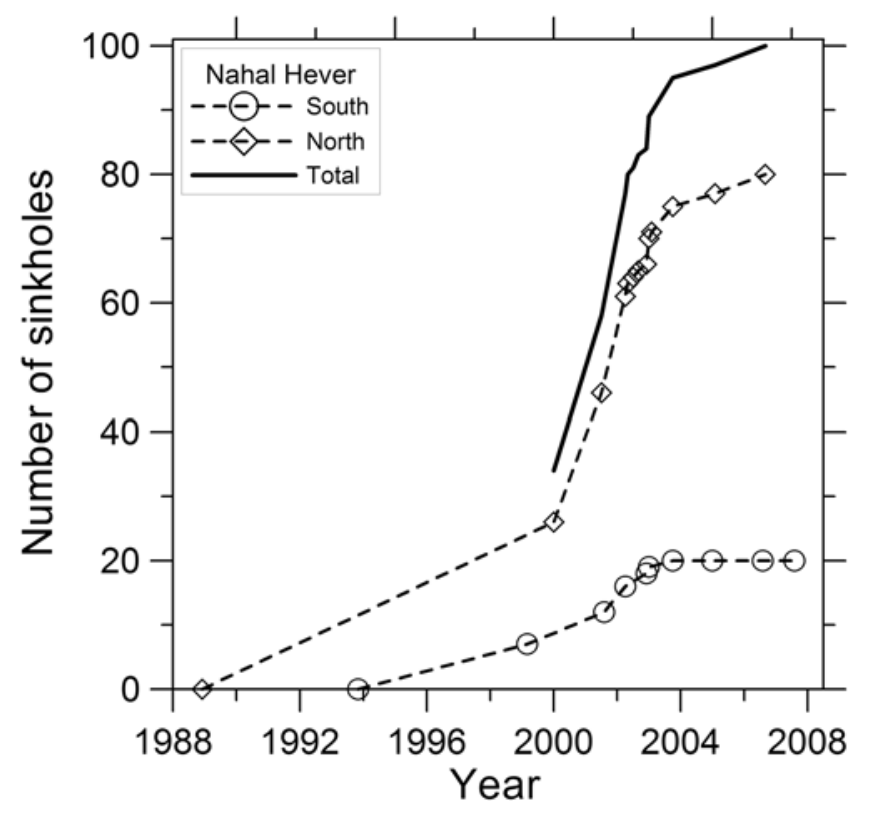

Figure 3. Number of sinkholes observed in Nahal Hever from 1993 to 2007 (GSI data).

2007]. Observations show that since 2004 the number of new sinkholes in the Nahal Hever area diminished (Figure 3), which confirms our geophysical results. Around the area, TEM monitoring revealed that the salinity of groundwater does not vary [Ezersky et al., 2008]. This result is confirmed by borehole monitoring of water salinity done by GSI [Yechieli, 2007].

[12] Caverns were detected by MRS in the western part of Ghor Al-Haditha (Jordan) in 2005. Three MRS soundings were done in 2005 and repeated at the same location in 2007. Comparison reveals that for one sounding, caverns were observed with MRS in $2005\left(T_{1} \approx 750 \mathrm{~ms}\right)$ but were not observed in 2007 ( $\left.T_{1} \approx 250 \mathrm{~ms}\right)$. Two other stations show that the subsurface did not change $\left(T_{1} \approx 250 \mathrm{~ms}\right.$ in 2005 and 2007). We conclude that most of the caverns that caused sinkholes are now filled with soil. In Ghor Al-Haditha sinkholes appeared approximately 5 years earlier than in Nahal Hever. So we expect that the scenario of sinkhole development is similar for these two sites but shifted in time.

[13] In total, 10 sites have been investigated in Israel using the seismic refraction method. At all 10 sites, it was found that sinkholes occur along the western edge of the salt formation [Ezersky et al., 2008]. In 2002, the total length of the sinkhole strip along the seashore had reached $60 \mathrm{~km}$. Thus, the average velocity of sinkhole expansion can be estimated at about $3 \mathrm{~km} / \mathrm{a}$. However, the width of the sinkhole strip is about $100 \mathrm{~m}$ and the spreading out of sinkholes transverse to the salt edge direction has not been observed.

\section{Discussion}

[14] Our results fully support the model based on the scheme of dissolution of buried salt that cause subsurface caverns and consequent sinkhole development. However, the velocity of salt dissolution needs to be discussed.

[15] Indeed, 3 major arguments support the fast dissolution assumption, which causes the development of large caverns in 10 to 20 years: (1) the Dead Sea level started decreasing in 1970 and first sinkholes appeared in 1990, this observation had been interpreted as an absence of subsurface caverns before 1970 [Shalev et al., 2006]; (2) sinkholes reappear after they have been refilled with soil, and this phenomenon had been interpreted as indicating a continuously increasing cavern volume; (3) numerical modeling reveals that under some specific conditions (existence of permeable faults in contact with a salt layer, relatively fresh water flowing through these faults, existence of a clay layer above the salt, and others), fast dissolution of salt rock with development of caverns would be possible [Shalev et al., 2006].

[16] However, our field observations do not confirm the fast dissolution scenario regarding the following points:

[17] 1. Field measurements performed in sinkhole affected areas do not confirm predictions made by the numerical modeling [Shalev et al., 2006]: (a) predicted less-conductive groundwater flow has not been observed in areas with existing sinkholes where the clay layer over salt formation should be broken down; (b) permeable faults necessary for the fast dissolution assumption were not detected with MRS, which is an efficient tool for detecting zones with high hydraulic conductivity.

[18] 2. The fast dissolution model does not explain why sinkholes are arranged in a narrow strip. The model assumes that caverns are caused by water flow through active faults. However, faults are very common in the area and should cause sinkholes to be more dispersed. Our results show that sinkholes are aligned not along the faults but along the salt formation edge thus explaining their arrangement in a strip.

[19] 3. Our results in the Nahal Hever and Ghor AlHaditha show that when sinkholes develop, caverns are filled with soil and the development of new caverns is not observed. These observations are confirmed by aero photographical monitoring, which also shows that development of new sinkholes in Nahal Hever slowed down.

[20] 4. Numerical modeling of the salt dissolution phenomenon performed using approximate physical parameters is questionable. The following uncertainties may affect modeling results: (a) the salt dissolution rate was derived from laboratory measurements using pure $\mathrm{NaCl}$ samples, which may differ from the dissolution rate of Dead Sea salt rock; (b) the effective specific surface area of Dead Sea salt rock is not known and could vary by order of magnitudes [Renard et al., 1998; Bercovici et al., 2001]; (c) mathematical non-uniqueness of the problem with poorly-constrained hydrologic and kinetic properties of the area proposes many different scenarios of salt dissolution, not all of them leading to the fast development of large caverns. Thus, the numerical modeling is able predicting what would happen under conditions set in the model but it cannot reproduce the phenomenon which is necessary for understanding what is really happening in the Dead Sea area.

[21] 5. In both Israel and Jordan, attempts were made to fill sinkholes with soil but refilled sinkholes reappear in a short period of time. It is one of the major arguments pointing to very rapid salt dissolution. However, this ob- 
servation can be explained if we assume not one but numerous interconnected caverns. Soil mixed with water (mud) is expanding into these caverns from refilled open pits. After some time the refilled hole reappears. Sinkholes should not reappear when existing caverns are full. Observations in Newer Zohar (Israel) and Ghor Al- Haditha (Jordan) confirm that some of sinkholes that have been refilled many times do not reopen.

[22] 6. Very rapid dissolution of buried salt is not an ordinary phenomenon. In the literature time necessary for creating large caverns is estimated as a few hundred years [Frumkin, 2000]. A few examples of much faster dissolution have been documented in several areas [Van Sambeek, 1996; Talbot et al., 2000; Mottershead et al., 2008]. However, in all these cases salt was exposed to intensive fresh water flow. Conditions reported for these examples are hardly compatible with that existing in the Dead Sea basin characterized by very saline water (more than $100 \mathrm{~g} / \mathrm{l}$ ) and relatively modest water flow. Contrary to the fast dissolution assumption, sinkholes caused by pre-existing caverns (paleokarst) and lowering of the groundwater level is a more common phenomenon [Gutiérrez et al., 2008].

[23] 7. The chemical analysis of groundwater in caverns reveals traces of the salt dissolution [Yechieli et al., 2006]. But these data provide no information about the velocity of dissolution.

[24] On the basis of our results we propose an outline of sinkhole development, which explains the field observations and does not require the very special conditions necessary for the fast dissolution of salt. Our model is based on the following assumptions: (1) slow dissolution of salt (much longer than 20 years) has caused caverns in the salt formation without development of sinkholes; (2) salt formation has preferentially dissolved along the edge because of its better contact with groundwater and less solid salt structure; (3) pre-existing caverns cause sinkholes development, this process was triggered by lowering of the groundwater level with a time delay imposed by mechanical properties and the thickness of rocks.

[25] However, our alternative model is only qualitative and we believe that for complete understanding of the sinkhole development it will be necessary to develop a numerical model of the phenomenon using reliable data about mechanical, hydrologic, and kinetic properties of the Dead Sea coastal area. For that: (1) the velocity of salt dissolution under Dead Sea conditions should be investigated in boreholes and in laboratory; (2) the mechanical strength of sedimentary rock overlaying caverns in salt formation should be studied; (3) mapping and monitoring of already existing caverns should be performed.

\section{Conclusions}

[26] The main goal of our geophysical investigation in Israel and Jordan was the verification of reported in the literature model explaining development of sinkholes in the Dead Sea region.

[27] Our geophysical results fully confirm the salt dissolution model: (1) large caverns in salt were reliably detected with MRS; (2) seismic measurements confirm that sinkholes develop only in presence of buried salt formation.
[28] However, our geophysical measurements performed in sinkholes affected areas do not confirm the assumption of the fast dissolution of salt rock, which causes the development of large caverns in 10 to 20 years. We explain development of sinkholes using a more ordinary scheme: (1) slow salt dissolution caused subsurface caverns; (2) sinkhole development is triggered by a lowering of the groundwater level, which causes the sedimentary rocks that overlie pre-existing caverns in the salt formation to become unsaturated; (3) the timing of the appearance of sinkholes is controlled by the groundwater level and the thickness and mechanical properties of the rocks.

[29] Acknowledgments. Our geophysical study in sinkhole-affected areas of Israel and Jordan has been carried out within the framework of the NATO Program for Security through Science (project SfP $N^{\circ}$ 981128). Authors are thankful to M. Abelson, E. Raz and Y. Yechieli for providing geological and hydrogeological data related to the sinkholes problem.

\section{References}

Abelson, M., G. Baer, V. Shtivelman, D. Wachs, E. Raz, O. Crouvi, I. Kurzon, and Y. Yechieli (2003), Collapse-sinkholes and radar interferometry reveal neotectonics concealed within the Dead Sea basin, Geophys. Res. Lett., 30(10), 1545, doi:10.1029/2003GL017103.

Abelson, M., A. Geller, and S. Alpassi (2007), Sinkhole development along the Dead Sea coast during January 2005-August 2006: Review of aero photograpy, GSI Rep. TR-GSI/07/2007, Geophys. Inst. Isr., Lod.

Arkin, Y., and A. Gilat (2000), Dead Sea sinkholes-An ever-developing hazard, Environ. Geol., 39(7), 711-722.

Bercovici, D., Y. Ricard, and G. Schubert (2001), A two-phase model for compaction and damage: 1. General theory, J. Geophys. Res., 106, $8887-$ 8906.

Ezersky, M. (2006), The seismic velocities of Dead Sea salt applied to the sinkhole problem, J. Appl. Geophys., 58, 45-58.

Ezersky, M., A. Legchenko, A. Al-Zoubi, and C. Camerlynk (2008), The Dead Sea sinkhole hazards - New findings based on the multidisciplinary geophysical study, Geophys. Res. Abstr., 10, EGU2008-A-06,209.

Frumkin, A. (2000), Salt speleogenesis, in Speleogenesis: Evolution of Karst Aquifers, edited by A. B. Klimchouk, D. C. Ford, and W. Dreybrodt, pp. 169-170, Natl. Speleological Soc., Huntsville, Ala.

Frumkin, A., and E. Raz (2001), Collapse and subsidence associated with salt karstification along the Dead Sea, Carbonates Evaporites, 16(2), $117-130$.

Garfunkel, Z., and Z. Ben-Avraham (1996), The Structure of the Dead Sea basin, Tectonophysics, 266, 155-176.

Gutiérrez, F., A. H. Cooper, and K. S. Johnson (2008), Identification, prediction, and mitigation of sinkhole hazards in evaporite karst areas, Environ. Geol., 53, 1007-1022, doi:10.1007/s00254-007-0728-4.

Kafri, U., M. Goldman, and B. Lang (1997), Detection of subsurface brines, freshwater bodies and the interface configuration in-between by the Time Domain Electromagnetic Method in the Dead Sea rift, Israel, Environ. Geol., 31, 42-49.

Legchenko, A., and P. Valla (2002), A review of the basic principles for proton magnetic resonance sounding measurements, J. Appl. Geophys, $50,3-19$.

Legchenko, A., M. Ezersky, C. Camerlink, A. Al-Zoubi, K. Chalikakis, and J.-F. Girard (2008), Locating water-filled karst caverns and estimating their volume using magnetic resonance soundings, Geophysics, in press. Mottershead, D. N., W. J. Duane, and R. J. Inkpen (2008), An investigation of the geometric controls on the morphological evolution of small-scale salt terrains, Cardona, Spain, Environ. Geol., 53, 1091-1098, doi:10.1007/s00254-07-0736-4.

Palmer, D. (1986), Refraction Seismics: The Lateral Resolution of Structure and Seismic Velocity, Handb. Geophys. Explor. Sect. I Seismic Explor. vol. 13, Geophysical, London.

Renard, F., J. P. Gratier, P. Ortoleva, E. Brosse, and B. Bazin (1998), Selforganization during reactive fluid flow in a porous media, Geophys. Res. Lett, , 25, 385-388.

Rybakov, M., V. Goldshmidt, L. Fleischer, and Y. Rotstein (2001), Cave detection and 4-d monitoring: A microgravity case history near the Dead Sea, Leading Edge, 20(8), 896-900, doi:10.1190/1.1487303.

Shalev, E., V. Lyakhovsky, and Y. Yechieli (2006), Salt dissolution and sinkhole formation along the Dead Sea shore, J. Geophys. Res., 111, B03102, doi:10.1029/2005JB004038.

Shtivelman, V. (1995), Kinematical inversion of first arrivals of refracted wave-A combined approach, Geophysics, 61, 509-519. 
Shtivelman, V., M. Goldman, A. Ronen, and M. Ezersky, (1999), Shallow geophysical surveys in the sinkhole development area at the Nahal Hever site, GII Rep. 823/87/98, Geophys. Inst. Isr., Lod.

Talbot, C. J., S. Medvedev, M. Alavi, H. Shahrivar, and E. Heidari (2000), Salt extrusion at Kuh-e-Jahani, Iran, from June 1994 to November 1997, Geol. Soc. Spec. Publ., 174, 93-110.

Taqieddin, S., N. Abderahman, and M. Atallah (2000), Sinkhole hazard along the eastern Dead Sea shoreline area, Jordan: A geological and geotechnical consideration, Environ. Geol., 39, 1237-1253.

Van Sambeek, L. L. (1996), Dissolution-induced mine subsidence at the Retsof Salt Mine, in Proceedings of the SMRI Fall Meeting, pp. 289309, Solution Min. Res. Inst., Cleveland, Ohio.

Vouillamoz, J.-M., A. Legchenko, Y. Albouy, M. Bakalowicz, J.-M. Baltassat, and W. Al-Fares (2003), Localization of saturated karst aquifer with magnetic resonance sounding and resistivity imagery, Ground Water, 41, 578-587.

Yechieli, Y. (2000), Fresh-Saline ground water interface in the western Dead Sea area, Ground Water, 38, 615-623.

Yechieli, Y. (2007), Geochemical monitoring of groundwater in boreholes at the Dead Sea coastal area-Project of sinkholes, GSI Rep. TR-GSI/18, 2007, Geophys. Inst. Isr., Lod.
Yechieli, Y., M. Abelson, A. Bein, O. Crouvi, and V. Shtivelman (2006), Sinkhole "swarms" along the Dead Sea coast: Reflection of disturbance of lake and adjacent groundwater systems, Geol. Soc. Am. Bull., 118, 1075-1087, doi:10.1130/B25880.1.

A. Al-Zoubi, Engineering Faculty, Al-Balqa' Applied University, Salt, 19117 Jordan. (aalzoubi@go.com.jo)

M. Boucher, HSM, Université de Montpellier 2, 34095 Montpellier Cedex 5, France. (Marie.Boucher@ird.fr)

C. Camerlynck, UMR 7619 Sisyphe, Université Pierre et Marie Curie (Paris 6), 4 place Jussieu, 75252 Paris Cedex 05, France. (camerl@ccr. jussieu.fr)

K. Chalikakis and A. Legchenko, LTHE, BP53, 38041 Grenoble Cedex 9, France. (konstantinos.chalikakis@hmg.inpg.fr; anatoli.legtchenko@ hmg.inpg.fr)

M. Ezersky, Geophysical Institute of Israel, 6 Haba'al Shem Tov Str. P.O. Box 182, Lod 71100, Israel. (mikhail@gii.co.il) 